\title{
Limnological characteristics of a reservoir in semiarid Northeastern Brazil subject to intensive tilapia farming (Orechromis niloticus Linnaeus, 1758)
}

Características limnológicas em um reservatório do semiárido brasileiro com cultivo intensivo de Orechromis niloticus (Linnaeus, 1758)

Luis Artur Valóes Bezerra ${ }^{1}$, Walt Disney Paulino², Danielle Sequeira Garcez ${ }^{3}$, Helena Becker ${ }^{4}$ and Jorge Iván Sánchez-Botero ${ }^{5}$

${ }^{1}$ Laboratório de Ecologia Aquática, Programa de Pós-graduação em Ciências Marinhas Tropicais, Departamento de Biologia, Centro de Ciências, Instituto de Ciências do Mar - LABOMAR, Universidade Federal do Ceará - UFC, Bloco 906, Campus do Pici, CEP 60455-760, Fortaleza, CE, Brazil e-mail: larturr@yahoo.com.br

${ }^{2}$ Companhia de Gestáo dos Recursos Hídricos - COGERH, Rua Adualdo Batista, 1550, Parque Iracema, CEP 60824-140, Fortaleza, CE, Brazil

e-mail:wdisneyp@gmail.com

${ }^{3}$ Instituto de Ciências do Mar - LABOMAR, Universidade Federal do Ceará - UFC, Avenida da Abolição, 3207, Meireles, CEP 60165-081, Fortaleza, CE, Brazil

e-mail: daniellegarcez@ufc.br

${ }^{4}$ Laboratório de Química Ambiental - LAQA, Departamento de Química Analítica e Físico-Química, Centro de Ciências, Universidade Federal do Ceará - UFC, Campus do Pici,

CEP 60455-760, Fortaleza, CE, Brazil e-mail: becker@ufc.br

${ }^{5}$ Laboratório de Ecologia Aquática, Departamento de Biologia, Centro de Ciências, Universidade Federal do Ceará - UFC, Bloco 906, Campus do Pici, CEP 60455-760, Fortaleza, CE, Brazil e-mail: jisbar.ufc@gmail.com

Abstract: Aim: There is currently no consensus regarding the physical and chemical variability of tropical reservoirs. In semiarid Northeastern Brazil, reservoirs are among other things used for human consumption, industrial water supply and intensive fish farming, all of which can impact water quality. The objective of this study was to evaluate the physical and chemical variability of the water in Sítios Novos, a reservoir in semiarid Northeastern Brazil, comparing samples collected in areas of intensive tilapia (Oreochromis niloticus) farming to samples from areas not directly impacted by aquaculture, in both the dry and the rainy season. Methods: Between October 2010 and July 2011, data were collected on temperature, conductivity, $\mathrm{pH}$, turbidity, salinity, chlorophyll $a$, dissolved oxygen, oxygen demand, total phosphorus and total nitrogen levels in the water column using a multiparametric probe at four different sampling locations. Physical and chemical differences between the four locations were evaluated with the Kruskal-Wallis (KW) test and Dunn's post test, while the $t$ test, followed by Welch's correction, was used to compare samples collected in different seasons. Results: No influence of intensive aquaculture was detected when comparing sampling locations near fish farms (180C and 300C) to locations not directly impacted by aquaculture (LIMN1, near the dam, and LIMN2, near the debouch of the São Gonçalo river). However, the sampling locations differed significantly $(\mathrm{p}<0.05)$ with regard to conductivity, $\mathrm{pH}$, turbidity and chlorophyll $a$ levels. Conclusions: The physical and chemical variability was greater between seasons than between locations when the data were analyzed with the $t$ test. That analysis showed significant differences for 22 of 40 comparisons between the 10 physical and chemical parameters in the two seasons at the four sampling locations. In conclusion, the physical and chemical variability registered for the Sítios Novos reservoir throughout the study period indicates morphometric, meteorological and hydrological heterogeneity, with emphasis on the differences between LIMN2 and the other three sampling locations and between the rainy season and the dry season. According to the calculated trophic status index, the reservoir is supereutrophic in the rainy season and supereutrophic to hypereutrophic in the dry season.

Keywords: fish farming, water quality, lentic ecosystem, morphometry, semiarid, Northeastern Brazil. 
Resumo: Objetivo: Atualmente, não há um consenso sobre a variabilidade física e química de reservatórios tropicais. No semiárido brasileiro, esses reservatórios são utilizados, entre outras finalidades, para consumo humano, abastecimento industrial, além de atividades de piscicultura intensiva, que podem alterar a qualidade da água. $\mathrm{O}$ objetivo deste estudo foi avaliar a variabilidade física e química da água do reservatório Sítios Novos, em áreas próximas à piscicultura intensiva de tilápia (Oreochromis niloticus) e em áreas afastadas dessa atividade, considerando períodos de chuva e estiagem. Métodos: Valores de temperatura, condutividade, $\mathrm{pH}$, turbidez, salinidade, clorofila $a$, oxigênio dissolvido, demanda de oxigênio, fósforo total e nitrogênio total foram obtidos na coluna da água com sonda multiparamétrica, em coletas entre outubro de 2010 e julho de 2011, em quatro pontos de amostragem. Uma análise de Kruskal-Wallis, com um teste posterior de Dunn, foi empregada para comparar a variação física e química da coluna da água entre os quatro pontos. Um teste $t$, com correçâo de Welch, foi empregado para comparar a coluna da água entre períodos de chuva e estiagem. Resultados: Não houve influência da atividade de piscicultura intensiva, quando comparadas as variáveis nas áreas próximas a tanques-rede (locais 180C e 300C), com variáveis no local próximo a barragem (LIMN1), e na região de entrada de efluentes provenientes do rio São Gonçalo (LIMN2). Entretanto, foram observadas diferenças significativas $(\mathrm{p}<0.05)$ entre os pontos de coleta para condutividade, $\mathrm{pH}$, turbidez e clorofila $a$. A maior variabilidade física e química foi entre períodos de estiagem e chuvas, comparados com o teste t. Das comparaçóes entre as 10 variáveis físicas e químicas, entre os dois períodos, nos pontos amostrados (totalizando 40 comparaçóes), 22 resultaram em diferenças estatisticamente significativas. Conclusão: Dessa forma, a variabilidade física e química ao longo do ano e entre épocas de chuva e estiagem reflete a heterogeneidade morfométrica, meteorológica e hidrológica do reservatório Sítios Novos, com destaque para as diferenças do local LIMN2 e pelas variaçôes entre períodos de seca e chuvas. Em ambos os períodos, o resevatório permanece eutrofizado, com maiores valores de fósforo total no período chuvas.

Palavras-chave: piscicultura, qualidade da água, ecossistema lêntico, morfometria, semi-árido, Nordeste do Brasil.

\section{Introduction}

Over the last decades an increasing number of studies have been conducted on the dynamics of the physical and chemical variability of reservoirs around the world in order to subsidize the management of these resources (Carpenter et al., 1995). Studies range from simple environmental surveys to complex analyses, such as hydrodynamic modeling (Lindim et al., 2011) and trophic network modeling (Carpenter et al., 2008). However, despite these efforts, no consensus has been reached regarding the physical and chemical variability of tropical reservoirs. To support the management of such complex ecosystems, future studies may need to adopt a more systemic and integrated approach (Tundisi, 2008).

The construction of dams and reservoirs in semiarid Northeastern Brazil was primarily intended to increase the storage capacity of water for urban and industrial supply and to perennialize the local hydrographic basins (Rebouças et al., 2006). However, an excessive number of reservoirs have been built, many of which small and shallow, creating a discontinuity between water bodies and compromising the efficiency of the water storage network (Medeiros et al., 2010).
Compared to water bodies in other regions of Brazil, reservoirs in semiarid areas are more susceptible to eutrophication due to highs average temperatures, evaporation and residence time. This scenario is worsened in periods of drought. In fact, the region is currently (2012-2013) undergoing the worst drought in the past 30 years (Novaes and Felix, 2013), and it has been hypothesized that in the 22nd century semiarid Northeastern Brazil may have to be reclassified as arid due to a gradual decrease in the rainfall/evaporation ratio, potentially intensified by global warming (Sherwood and Fu, 2014).

Reservoirs surrounded and exploited by businesses or large communities are highly susceptible to the effects of aridity and eutrophication. This is the case of the Sítios Novos reservoir in Ceará, a state in Northeastern Brazil. The reservoir is subject to heavy water demands from local irrigated farms and the industry (Barbosa et al., 2012). Along the shores are several brickyards, intensive aquaculture facilities and a system of pipelines which supply water for irrigation and to the industrial zone associated with the Port of Pecém.

Despite the introduction of an increasing number of aquaculture regulations, especially in 
developing countries throughout Latin America, fish farming management and monitoring methods remain inefficient and, in some cases, detrimental to the environment (Naylor et al., 2000; Coze and Nava, 2009; Wang et al., 2010). Although concern about the environmental impact of fish farming has been growing since the early 1990s, fishing productivity is still the decisive factor for implementation (Dias et al., 2012a).

Aquaculture is associated with a number of impacts, chief among which are increased concentrations of nitrogenated compounds (Borges et al., 2010; Ansah et al., 2012), the introduction of exotic species (Naylor et al., 2000) and the destabilization of the trophic network (Borges et al., 2010; Dias et al., 2012b). Thus, in the Paranoá lake, a reduction in the biomass of farmed tilapia (from 900 to $350 \mathrm{~kg} \cdot \mathrm{ha}^{-1}$ ) lead to improvements in water quality due to a significant decrease in turbidity $(-46 \%)$, total phosphorus concentration $(-31 \%)$, microalgal blooms $(-70 \%)$ and phytoplankton biomass (-38\%) (Starling et al., 2002).

The objective of this study was to evaluate the physical and chemical variability of the water in the Sítios Novos reservoir (Ceará, Brazil), comparing samples collected in areas of intensive tilapia (Oreochromis niloticus) farming to samples from areas not directly impacted by aquaculture, in both the dry season and the rainy season.

\section{Material and Methods}

\subsection{Study area}

The Sítios Novos reservoir (3'45'54.21"S and $\left.38^{\circ} 58^{\prime} 26.37^{\prime \prime} \mathrm{W}\right)$ is located in the São Gonçalo river basin in Ceará, Northeastern Brazil. It features a zoned-earth dam and a bed consisting of planosols and solodic planosols, a surface area of $16.48 \mathrm{~km}^{2}$ and a storage capacity of 126 million cubic meters (COGERH, 2008) (Figure 1). According to the updated Köppen classification, the region may be defined as tropical savanna, between Bsh and Aw, which means hot, dry and semiarid (Peel et al., 2007).

\subsection{Sampling}

Between October 2010 and July 2011, eight visits to the reservoir were made in order to collect physical and chemical data. Four sampling locations were defined and labeled "180C", "300C", "LIMN1" and "LIMN2". The first two were areas of intensive tilapia farming, featuring approximately
180 and 300 cages, respectively. LIMN1 was in the limnetic zone near the dam, between $180 \mathrm{C}$ and $300 \mathrm{C}$, at approximately $500 \mathrm{~m}$ from the nearest area of intensive aquaculture. LIMN2 was in a shallow area near the debouch of the São Gonçalo river, characterized by ombrophilous and deciduous vegetation (Copernicia prunifera) and far removed from any form of aquacultural activity (Figure 1).

The study variables were measured at all four sampling locations in the morning hours (9-12 a.m.). Initially, the total depth was registered with a Speedtech ${ }^{\circledR}$ SM-5 device. Then a multiparameter probe (YSI ${ }^{\circledR}$ V26600) was employed to measure the temperature $\left({ }^{\circ} \mathrm{C}\right)$, conductivity $\left(\mu \mathrm{S} . \mathrm{cm}^{-1}\right)$, salinity (ppm), turbidity (NTU), $\mathrm{pH}$, chlorophyll a $\left(\mu \mathrm{g} . \mathrm{L}^{-1}\right)$, oxygen saturation $(\%)$ and dissolved oxygen (mg. $\mathrm{L}^{-1}$ ) starting at $0.3 \mathrm{~m}$ from the surface, then descending at $0.5 \mathrm{~m}$ intervals until reaching a distance of $0.5 \mathrm{~m}$ from the reservoir bottom.

Total phosphorous and nitrogen concentrations were based on samples collected at a depth of $0.3 \mathrm{~m}$ in March, July and October 2010, as well as in March and May 2011, and analyzed at the Laboratory of Environmental Chemistry (LAQA/ Federal University of Ceará) using the simultaneous persulphate digestion method proposed in "Standard Methods for the Examination of Water and Wastewater", issued by the American Public Health Association (APHA, 2005).

Climate data for the study location and period, including environmental temperature and monthly rainfall (Figure 2), were obtained from the website of a government meteorology service (www.funceme. br, accessed in October 2011). Wind speeds were measured in the field with a portable digital anemometer $\left(\right.$ Incoterm $\left.^{\circledR}\right)$.

\subsection{Data analysis}

The physical and chemical variables obtained from the four sampling locations were entered consecutively in separate spreadsheets (180C, 300C, LIMN1 and LIMN2), with one column for each variable, intersected by sampling month and depth, covering a total period of eight months. Mean, minimum and maximum values, variation coefficients and standard deviations were then calculated for the entire period (Table 1). Subsequently, sampling depth $(0.3 \mathrm{~m}, 0.5 \mathrm{~m}, 1 \mathrm{~m}$, $1.5 \mathrm{~m}, 2 \mathrm{~m}, 2.5 \mathrm{~m}$ and $3 \mathrm{~m}$ ) means of each variable were compared between the four sampling locations using the Kruskal-Wallis test, followed by Dunn's post test (Table 2) (Zar, 2010). 


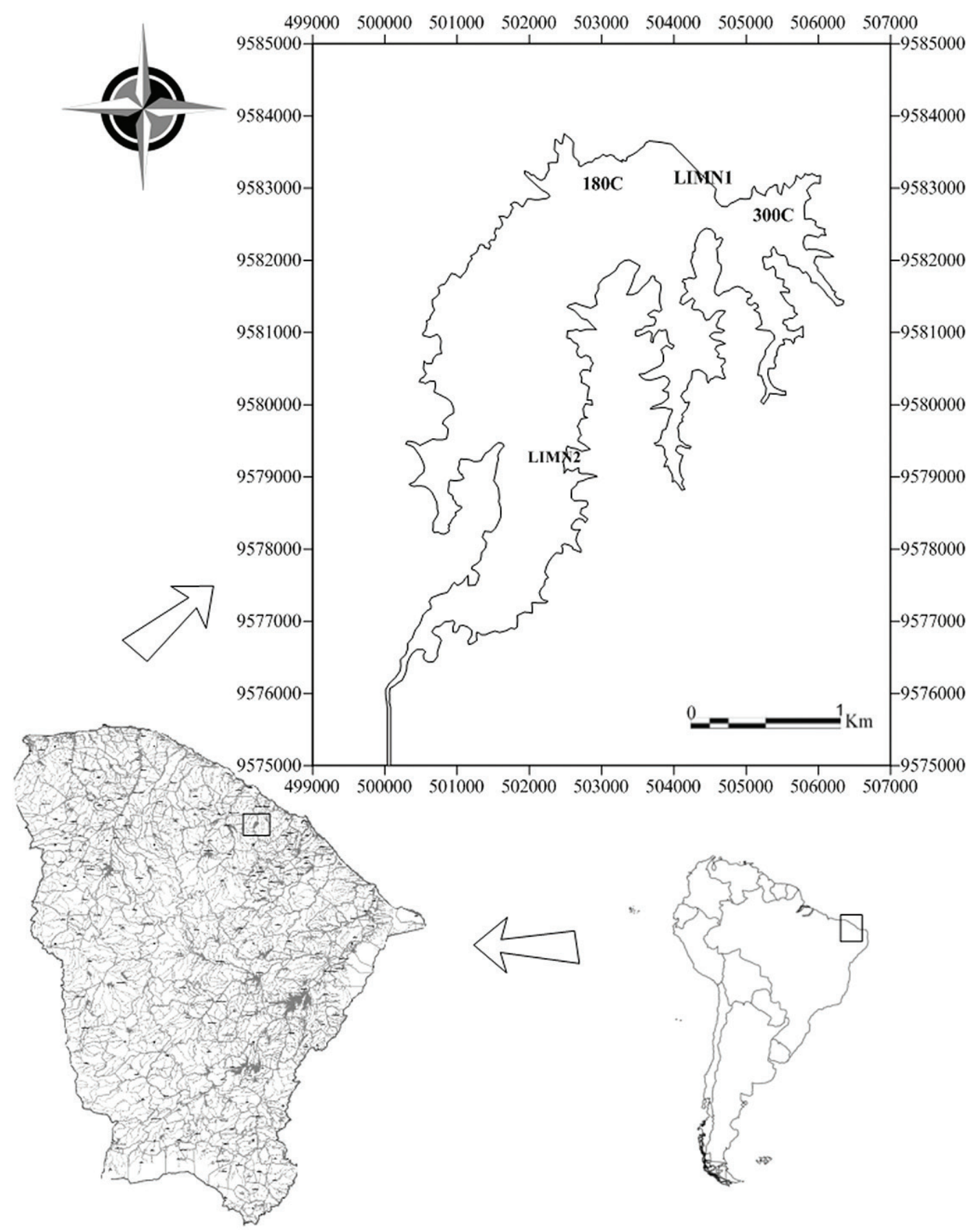

Figure 1. Location of the Sítios Novos reservoir in Ceará, Brazil, showing the four sampling locations in bold (180C, 300C, LIMN1 and LIMN2). Source of Ceará map: Mapeamento dos Espelhos d'Água do Brasil, modified of FUNCEME (2011a); figure produced with Surfer 11 (Golden Software, 2013).

The collected physical and chemical variables were also segregated by season, as defined by historical rainfall indices for the past 30 years in the study area (Figure 2). Thus, the dry season included October, November and December 2010, and June and July 2011, whereas the rainy season included February, March and April 2010.
A separate spreadsheet was used for each season, with one column for each sampling location and month, intersected by the respective sampling depths. Mean, minimum and maximum values, variation coefficients and standard deviations were then calculated and compared for the two seasons (Table 3). 
Table 1. Physical and chemical data collected at four sampling locations (180C, 300C, LIMN1 and LIMN2) in the Sítios Novos reservoir (Ceará, Brazil) during eight months between October 2010 and July 2011.

\begin{tabular}{|c|c|c|c|c|c|c|c|c|c|c|c|}
\hline Site & & Temp & Cond & $\mathrm{S}$ & $\mathrm{pH}$ & Turb & Chl a & OD & DO & TP & TN \\
\hline \multirow[t]{5}{*}{$180 \mathrm{C}$} & Mean & 28.35 & 0.53 & 0.24 & 7.50 & 13.24 & 13.71 & 59.46 & 4.62 & 0.21 & 2.30 \\
\hline & SD & 0.48 & 0.03 & 0.02 & 0.27 & 5.93 & 11.43 & 25.43 & 1.98 & 0.10 & 1.19 \\
\hline & VC\% & 1.69 & 5.75 & 6.86 & 3.58 & 44.82 & 83.33 & 42.77 & 42.82 & 49.54 & 51.88 \\
\hline & $M x$ & 29.71 & 0.61 & 0.28 & 8.65 & 28.10 & 36.60 & 112.2 & 8.51 & 0.32 & 4.01 \\
\hline & $\mathrm{Mn}$ & 27.61 & 0.49 & 0.22 & 6.81 & 0.10 & 3.10 & 2.00 & 0.16 & 0.07 & 0.77 \\
\hline \multirow[t]{5}{*}{$300 \mathrm{C}$} & Mean & 28.21 & 0.53 & 0.24 & 7.43 & 11.80 & 12.42 & 52.19 & 4.06 & 0.15 & 2.06 \\
\hline & SD & 0.57 & 0.03 & 0.02 & 0.35 & 4.18 & 10.67 & 27.18 & 2.09 & 0.08 & 0.66 \\
\hline & VC\% & 2.03 & 6.38 & 6.99 & 4.75 & 35.39 & 85.94 & 52.09 & 51.60 & 51.48 & 32.02 \\
\hline & $M x$ & 29.9 & 0.61 & 0.28 & 8.67 & 21.30 & 37.50 & 121.0 & 9.15 & 0.25 & 3.01 \\
\hline & $\mathrm{Mn}$ & 26.93 & 0.49 & 0.22 & 6.71 & 3.10 & 3.60 & 2.10 & 0.17 & 0.06 & 1.41 \\
\hline \multirow[t]{5}{*}{ LIMN1 } & Mean & 28.38 & 0.53 & 0.24 & 7.78 & 12.52 & 11.36 & 63.33 & 4.92 & 0.18 & 1.43 \\
\hline & SD & 0.45 & 0.03 & 0.02 & 0.39 & 4.47 & 9.73 & 27.44 & 2.12 & 0.03 & 0.57 \\
\hline & VC\% & 1.59 & 5.95 & 6.58 & 4.96 & 35.74 & 85.65 & 43.33 & 43.11 & 14.56 & 39.95 \\
\hline & $M x$ & 29.57 & 0.60 & 0.27 & 8.7 & 26.0 & 35.70 & 122.0 & 9.28 & 0.21 & 2.26 \\
\hline & $\mathrm{Mn}$ & 27.29 & 0.49 & 0.22 & 7.14 & 1.30 & 4.30 & 2.60 & 0.20 & 0.15 & 0.85 \\
\hline \multirow[t]{5}{*}{ LIMN2 } & Mean & 28.34 & 0.52 & 0.23 & 7.84 & 17.16 & 13.55 & 68.91 & 5.34 & 0.19 & 1.79 \\
\hline & SD & 0.59 & 0.06 & 0.03 & 0.44 & 8.31 & 12.54 & 29.82 & 2.29 & 0.11 & 0.55 \\
\hline & VC\% & 2.09 & 11.22 & 11.44 & 5.61 & 48.69 & 93.08 & 43.52 & 43.09 & 60.86 & 30.60 \\
\hline & $M x$ & 30.31 & 0.59 & 0.26 & 8.98 & 44.40 & 44.90 & 151.2 & 11.36 & 0.34 & 2.53 \\
\hline & $\mathrm{Mn}$ & 26.90 & 0.30 & 0.14 & 7.06 & 5.30 & 4.30 & 2.60 & 0.21 & 0.08 & 1.38 \\
\hline
\end{tabular}

$\mathrm{SD}=$ Standard Deviation; $\mathrm{VC} \%=$ percentage variation coefficient; $\mathrm{Mx}-\mathrm{Mn}=$ maximum and minimum values; Temp=temperature $\left({ }^{\circ} \mathrm{C}\right) ;$ Cond=conductivity $\left(\mu \mathrm{s} . \mathrm{cm}^{-1}\right) ; S=$ salinity (ppt); Turb=turbidity (NTU); Chl $a=$ chlorophyll $a\left(\mu \mathrm{g} . \mathrm{L}^{-1}\right) ; \mathrm{OD}=$ oxygen demand (\%); $\mathrm{DO}=$ dissolved oxygen $\left(\mathrm{mg} . \mathrm{L}^{-1}\right) ; \mathrm{TP}=$ Total phosphorus $\left(\mathrm{mg} . \mathrm{L}^{-1} \mathrm{P}\right) ; \mathrm{NT}=$ Total nitrogen $\left(\mathrm{mg} \cdot \mathrm{L}^{-1} \mathrm{~N}\right)$.

Table 2. Results of the Kruskal-Wallis (KW) test and the Dunn post test for physical and chemical data collected at four sampling locations (180C, 300C, LIMN1 and LIMN2) in the Sítios Novos reservoir (Ceará, Brazil) during eight months between October 2010 and July 2011.

\begin{tabular}{|c|c|c|c|c|c|c|c|c|c|c|}
\hline & Temp & Cond & S & $\mathrm{pH}$ & Turb & Chl a & OD & DO & TP & TN \\
\hline $\mathrm{P}$ & 0.95 & $<0.01$ & $n s^{*}$ & $<0.01$ & $<0.01$ & $<0.01$ & 0.33 & 0.30 & 0.72 & 0.35 \\
\hline KW & 0.30 & 14.51 & $\mathrm{~ns}^{*}$ & 19.45 & 10.97 & 23.04 & 3.42 & 3.62 & 1.30 & 3.26 \\
\hline Sites & & Dunn & & Dunn & Dunn & Dunn & & & & \\
\hline $180 \mathrm{C}-300 \mathrm{C}$ & & $p>0.05$ & & $p>0.05$ & $p>0.05$ & $p<0.01$ & & & & \\
\hline 180C-LIMN1 & & $p<0.05$ & & $p<0.05$ & $p>0.05$ & $p<0.01$ & & & & \\
\hline 180C-LIMN2 & & $p>0.05$ & & $p<0.01$ & $p>0.05$ & $p<0.05$ & & & & \\
\hline 300C-LIMN1 & & $p>0.05$ & & $p<0.05$ & $p>0.05$ & $p<0.05$ & & & & \\
\hline 300C-LIMN2 & & $p>0.05$ & & $p<0.05$ & $p<0.05$ & $p<0.05$ & & & & \\
\hline LIMN1-LIMN2 & & $p>0.05$ & & $p>0.05$ & $p<0.05$ & $p<0.05$ & & & & \\
\hline
\end{tabular}

${ }^{*}$ ns=non-significant difference. Temp $=$ temperature $\left({ }^{\circ} \mathrm{C}\right)$; Cond=conductivity $\left(\mu \mathrm{s} . \mathrm{cm}^{-1}\right) ; S=$ salinity (ppt); Turb=turbidity (NTU); Chl $a=$ chlorophyll $a\left(\mu \mathrm{g} . \mathrm{L}^{-1}\right)$; OD=oxygen demand (\%); DO=dissolved oxygen $\left(\mathrm{mg} \cdot \mathrm{L}^{-1}\right)$; $\mathrm{TP}=$ Total phosphorus $\left(\mathrm{mg} . \mathrm{L}^{-1} \mathrm{P}\right) ; \mathrm{TN}=$ Total nitrogen $\left(\mathrm{mg} . \mathrm{L}^{-1} \mathrm{~N}\right)$.

Finally, the mean values for each depth, from $0.3 \mathrm{~m}$ down to the maximum depth at each sampling location (180C, 300C, LIMN1 and LIMN2), segregated by season (dry and rainy), were organized side by side on a spreadsheet. The two seasons were compared with the $t$ test followed by Welch's correction (Welch, 1951) for unequal variances (Table 4). In the dry season, $180 \mathrm{C}$ was the deepest location $(9.5 \mathrm{~m})$, followed by $300 \mathrm{C}(7.5 \mathrm{~m})$, LIMN1 $(5.5 \mathrm{~m})$ and LIMN2 $(3 \mathrm{~m})$. In the rainy season, the corresponding depths were $10 \mathrm{~m}, 8 \mathrm{~m}$, $7 \mathrm{~m}$ and $6 \mathrm{~m}$.
The trophic state index of the Sítios Novos reservoir was calculated according to CETESB (2009), which is based on Carlson indices (1977) modified for total phosphorus and chlorophyll $a$, while leaving transparency out of the calculus, as in the following equation:

$\mathrm{TSI}=(\mathrm{TSI}(\mathrm{TP})+\mathrm{TSI}(\mathrm{Chl} a)) / 2$

where TSI is the trophic state index, TSI (TP) is the trophic state index for total phosphorus in the reservoir, and TSI $(\mathrm{Chl} a)$ is the trophic state index for chlorophyll $a$ in the reservoir. 


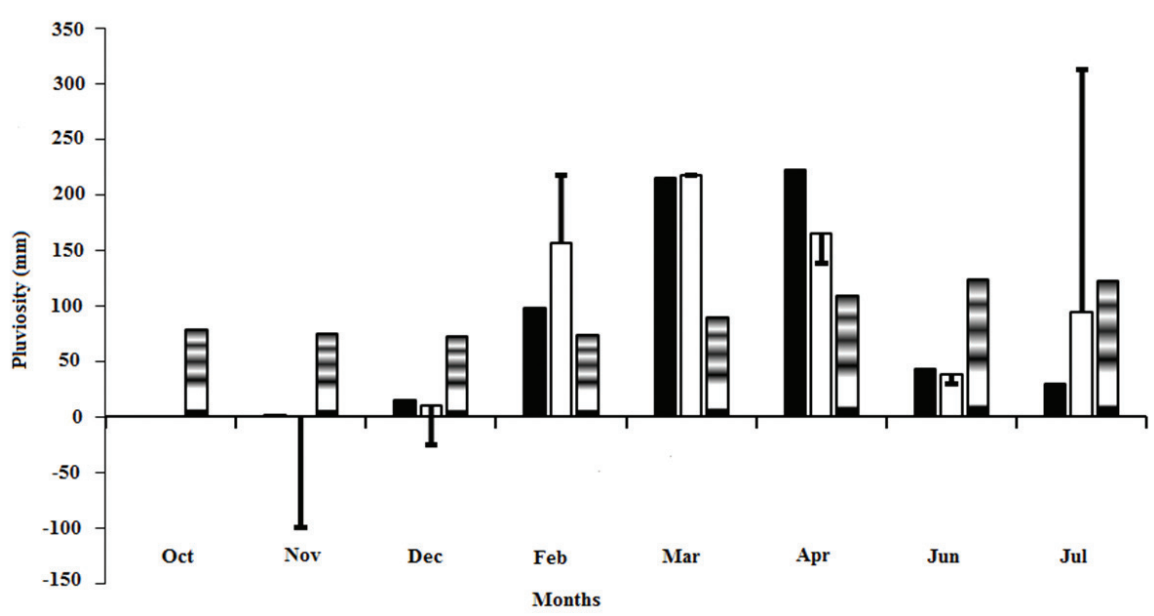

Figure 2. Rainfall (white bars) between October 2010 and July 2011 (except January and May) and standard deviation (lines) in the region where the Sítios Novos reservoir is located. Black bars indicate historical (last 30 years) mean rainfall for the same months. Hatched bars represent the volume of the expected annual quota of water in the reservoir at each month (Data source: FUNCEME, 2011b).

Table 3. Mean values, standard deviation, percentage variation coefficient, maximum and minimum values of physical and chemical data collected at four sampling locations (180C, 300C, LIMN1 and LIMN2) in the Sítios Novos reservoir (Ceará, Brazil) during the rainy season and the dry season (2010-2011).

\begin{tabular}{lrlllrrrrrr}
\hline \multicolumn{1}{c}{ Rainy } & Temp & Cond & S & pH & Turb & \multicolumn{1}{c}{ Chl a } & \multicolumn{1}{c}{ OD } & \multicolumn{1}{c}{ DO } & \multicolumn{1}{c}{ TP } & \multicolumn{1}{c}{ TN } \\
\hline Mean & 28.63 & 0.52 & 0.23 & 7.60 & 10.82 & 6.17 & 49.59 & 3.82 & 0.22 & 1.88 \\
SD & 0.30 & 0.03 & 0.01 & 0.41 & 4.54 & 13.2 & 12.66 & 0.97 & 0.07 & 0.89 \\
VC\% & 1.07 & 5.21 & 4.59 & 5.28 & 26.46 & 65.61 & 16.79 & 16.57 & 33.16 & 47.25 \\
Mx & 29.05 & 0.61 & 0.24 & 8.98 & 44.40 & 11.00 & 151.20 & 11.30 & 0.34 & 4.01 \\
Mn & 27.99 & 0.30 & 0.23 & 6.71 & 0.10 & 3.11 & 2.00 & 0.16 & 0.14 & 0.77 \\
\hline \multicolumn{1}{c}{ Dry } & & & & & & & & & & \\
\hline Mean & 28.15 & 0.54 & 0.24 & 7.61 & 16.26 & 20.67 & 72.56 & 5.67 & 0.12 & 1.92 \\
SD & 0.21 & 0.03 & 0.01 & 0.39 & 4.26 & 12.35 & 18.44 & 1.42 & 0.06 & 0.69 \\
VC\% & 0.77 & 4.79 & 4.36 & 5.13 & 26.22 & 59.74 & 25.42 & 25.09 & 51.17 & 35.82 \\
Mx & 28.78 & 0.59 & 0.26 & 8.74 & 28.90 & 44.90 & 117.40 & 9.02 & 0.22 & 3.01 \\
Mn & 27.67 & 0.49 & 0.23 & 6.80 & 8.10 & 8.30 & 20.60 & 1.63 & 0.06 & 1.21 \\
\hline
\end{tabular}

$\mathrm{SD}=$ Standard Deviation; $\mathrm{VC} \%=$ percentage variation coefficient; $\mathrm{Mx}-\mathrm{Mn}=$ maximum and minimum values; Temp=temperature $\left({ }^{\circ} \mathrm{C}\right)$; Cond=conductivity $\left(\mu \mathrm{s} . \mathrm{cm}^{-1}\right) ; \mathrm{S}=$ salinity (ppt); Turb=turbidity $(\mathrm{NTU})$; Chl $a=$ chlorophyll $a\left(\mu \mathrm{g} . \mathrm{L}^{-1}\right) ; \mathrm{OD}=$ oxygen demand $(\%) ; \mathrm{DO}=$ dissolved oxygen $\left(\mathrm{mg} . \mathrm{L}^{-1}\right) ; \mathrm{TP}=$ Total phosphorus $\left(\mathrm{mg} . \mathrm{L}^{-1} \mathrm{P}\right) ; \mathrm{TN}=$ Total nitrogen $\left(\mathrm{mg} \cdot \mathrm{L}^{-1} \mathrm{~N}\right)$.

Table 4. Results of the $t$ test followed by Welch's correction for physical and chemical data collected at four sampling locations (180C, 300C, LIMN1 and LIMN2) in the Sítios Novos reservoir (Ceará, Brazil), comparing the rainy season to the dry season (2010-2011).

\begin{tabular}{|c|c|c|c|c|c|c|c|c|c|c|c|}
\hline & & Temp & Cond & $s$ & $\mathrm{pH}$ & Turb & Chl a & OD & DO & TP & $\mathrm{TN}$ \\
\hline $180 \mathrm{C}$ & $\begin{array}{c}\mathrm{p} \\
\mathrm{W}\end{array}$ & $\begin{array}{l}<0.01 \\
18.20\end{array}$ & $\begin{array}{l}<<0.01 \\
13.90\end{array}$ & $\mathrm{~ns}^{*}$ & $\begin{array}{l}0.68 \\
0.40\end{array}$ & $\begin{array}{r}<0.01 \\
7.75\end{array}$ & $\begin{array}{l}<<0.01 \\
65.52\end{array}$ & $\begin{array}{c}<0.01 \\
6.63\end{array}$ & $\begin{array}{c}<0.01 \\
6.90\end{array}$ & $\begin{array}{l}0.34 \\
1.20\end{array}$ & $\begin{array}{l}0.09 \\
0.92\end{array}$ \\
\hline $300 \mathrm{C}$ & $\stackrel{p}{\mathrm{w}}$ & $\begin{array}{r}<0.01 \\
5.66\end{array}$ & $\begin{array}{l}0.29 \\
1.07\end{array}$ & $n s^{*}$ & $\begin{array}{l}0.02 \\
2.50\end{array}$ & $\begin{array}{r}<0.01 \\
4.14\end{array}$ & $\begin{array}{l}<0.01 \\
37.77\end{array}$ & $\begin{array}{l}0.04 \\
2.05\end{array}$ & $\begin{array}{l}0.03 \\
2.20\end{array}$ & $\begin{array}{l}0.05 \\
3.32\end{array}$ & $\begin{array}{l}0.80 \\
0.30\end{array}$ \\
\hline LIMN1 & $\begin{array}{c}\mathrm{p} \\
\mathrm{W}\end{array}$ & $\begin{array}{r}<0.01 \\
6.50\end{array}$ & $\begin{array}{r}<0.01 \\
7.38\end{array}$ & $\mathrm{~ns}^{*}$ & $\begin{array}{l}0.43 \\
0.78\end{array}$ & $\begin{array}{r}<0.01 \\
3.88\end{array}$ & $\begin{array}{l}<0.01 \\
37.39\end{array}$ & $\begin{array}{l}0.03 \\
2.28\end{array}$ & $\begin{array}{l}0.02 \\
2.48\end{array}$ & $\begin{array}{l}0.78 \\
0.30\end{array}$ & $\begin{array}{l}0.50 \\
0.84\end{array}$ \\
\hline LIMN2 & $\stackrel{p}{\mathrm{w}}$ & $\begin{array}{l}0.23 \\
1.29\end{array}$ & $\begin{array}{r}<0.01 \\
7.76\end{array}$ & $\mathrm{~ns}^{*}$ & $\begin{array}{l}0.54 \\
0.63\end{array}$ & $\begin{array}{r}<0.01 \\
6.98\end{array}$ & $\begin{array}{l}<0.01 \\
52.72\end{array}$ & $\begin{array}{l}0.04 \\
0.07\end{array}$ & $\begin{array}{l}0.07 \\
2.09\end{array}$ & $\begin{array}{l}0.10 \\
2.79\end{array}$ & $\begin{array}{l}0.17 \\
2.05\end{array}$ \\
\hline
\end{tabular}

${ }^{*}$ ns=non-significant difference. $\mathrm{p}=$ result of $t$ test; W=result of Welch's correction; Temp=temperature $\left({ }^{\circ} \mathrm{C}\right)$; Cond=conductivity $\left(\mathrm{ms} . \mathrm{cm}^{-1}\right) ; \mathrm{S}=$ salinity (ppt); Turb=turbidity (NTU); Chl $a=$ chlorophyll $a\left(\mu \mathrm{g} . \mathrm{L}^{-1}\right)$; OD=oxygen demand (\%); $\mathrm{DO}=$ dissolved oxygen $\left(\mathrm{mg} \cdot \mathrm{L}^{-1}\right) ; \mathrm{TP}=$ Total phosphorus $\left(\mathrm{mg} \cdot \mathrm{L}^{-1} \mathrm{P}\right) ; \mathrm{TN}=$ Total nitrogen $\left(\mathrm{mg} . \mathrm{L}^{-1} \mathrm{~N}\right)$. 
The morphometric variables "maximum depth" (Zmax) and "average depth" $(\mathrm{Za})$ were calculated from the depth data collected in the field with a portable sounder (Speedtech ${ }^{\circledR}$ SM-5). The reservoir surface area $(\mathrm{A})$ and perimeter $(\mathrm{P})$, the shoreline development index (Ds) and the volume development index (Dv) were calculated with GIS (Geographic Information Systems) operations using the software gvSIG (Asociación gvSIG, 2014) and Surfer 11 (Golden Software, 2013). These variables were used to determine the total storage capacity $(\mathrm{Ct})$, total volume $(\mathrm{V})$ and relative depth $(\mathrm{Zr})$ of the reservoir (Table 5).

Soundings obtained with a digital depth finder (datum WGS84) on August 2013 were used to determine the bathymetry of the Sítios Novos reservoir. The software SisBaHiA ${ }^{\circledR}$ (Fundação

Table 5. Morphometric data for the Sítios Novos reservoir (Ceará, Brazil), 2010-2011.

\begin{tabular}{ccc}
\hline Parameters & Values & Unity \\
\hline $\mathrm{A}$ & 16.48 & $\mathrm{Km}^{2}$ \\
$\mathrm{P}$ & 64.13 & $\mathrm{Km}$ \\
$\mathrm{V}$ & $125.9 \times 10^{6}$ & $\mathrm{~m}^{3}$ \\
$\mathrm{Ct}$ & $126 \times 10^{6}$ & $\mathrm{~m}^{3}$ \\
Zmax & 11.65 & $\mathrm{~m}$ \\
Za & 7.64 & $\mathrm{~m}$ \\
Zr & 0.25 & $\%$ \\
Ds & 4.76 & - \\
Dv & 2.02 & - \\
\hline
\end{tabular}

$\mathrm{A}=$ surface area; $\mathrm{P}=$ perimeter/length; $\mathrm{V}=$ total volume; $\mathrm{Ct}=$ total capacity; $\mathrm{Zmax}=$ maximum depth; $\mathrm{Za}=$ average depth; $\mathrm{Zr}=$ relative depth; Ds=shoreline development index; $\mathrm{Dv}=$ volume development index.
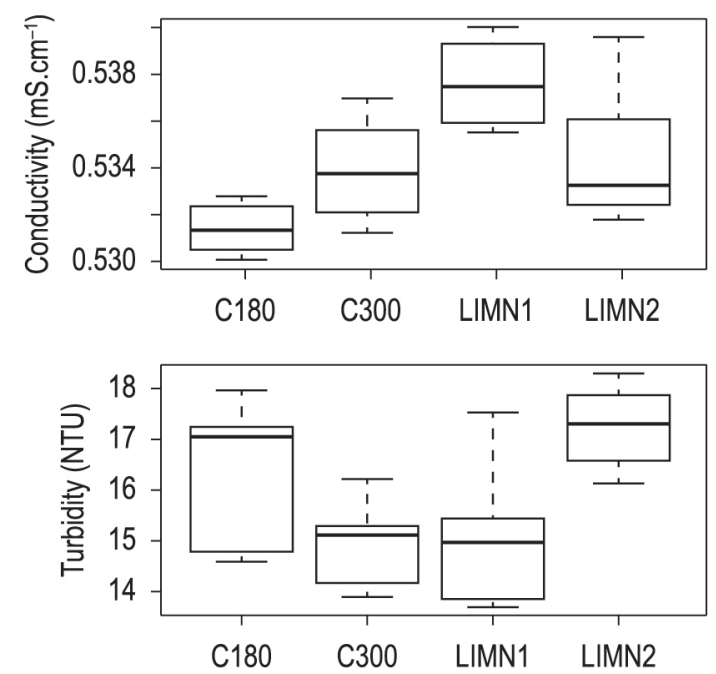

Figure 3. Amplitude variation (boxes), median values (lines inside boxes) and standard deviation (bars) for conductivity, $\mathrm{pH}$, turbidity, chlorophyll $a$ levels at four sampling locations (C180, C300, LIMN1 and LIMN2) in the Sítios Novos reservoir, 2010-2011 (R Development Core Team, 2013).
COPPETEC, 2013), made available by courtesy of the developers, was used to interpolate the data with the Kriging method. Finally, a bathymetry chart was drawn with the software Surfer 11 (Golden Software, 2013).

\section{Results}

The physical and chemical variables registered for the Sítios Novos reservoir in 2010-2011 yielded variation coefficients above 35\% for turbidity, chlorophyll $a$, dissolved oxygen and oxygen demand (the most unstable parameters in the water column) (Table 1). Conductivity and salinity varied by less than 0.2 units across the samples from the four sampling locations. Temperatures and $\mathrm{pH}$ values varied little at the four sampling locations (greatest VC\% $=2.09$ and 5.61, respectively, both at LIMN2). In contrast, total phosphorus (VC\% 14.56-60.86) and nitrogen (VC\% 30.60-51.88) yielded large variation coefficients (Table 1).

Location LIMN2 differed significantly $(\mathrm{p}<0.05$, Kruskal-Wallis test) from the other three sampling locations (180C, 300C and LIMN1) with regard to conductivity, $\mathrm{pH}$, turbidity and chlorophyll $a$. This last variable displayed the greatest variation between sampling locations (Table 2, Figure 3).

At LIMN2, the average depth $(5.2 \pm 1.5 \mathrm{~m})$ was small and the average turbidity $(17.1 \pm 8.3 \mathrm{NTU})$ was high when compared to average maximum values at the other three locations (depth $=180 \mathrm{C}$ : $9.7 \pm 0.9 \mathrm{~m} ; 300 \mathrm{C}: 9.5 \pm 1.1 \mathrm{~m}$; LIMN1: $9.0 \pm 3.0 \mathrm{~m}$; and turbidity $=180 \mathrm{C}: 13.2 \pm 5.9 \mathrm{NTU}$; 300C: $11.8 \pm 4.1 \mathrm{NTU}$; LIMN1: $12.5 \pm 4.4 \mathrm{NTU})$.
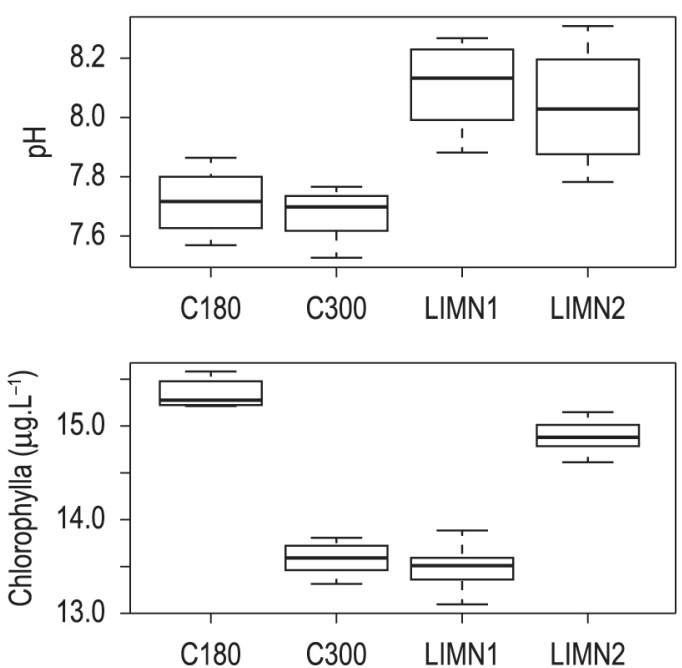
On the other hand, the four sampling locations did not differ significantly with regard to temperature, salinity, dissolved oxygen, oxygen demand, total phosphorus or total nitrogen.

The variation coefficients were greater in rainy months than in dry months, with the exception of dissolved oxygen and oxygen demand. As in the comparison between sampling locations, chlorophyll $a$ levels presented the greatest temporal variation ( $\mathrm{VC} \%$ values up to 65.61 in rainy months, and up to 59.74 in dry months), with a three-fold increase in average values between the rainy and the dry season $\left(6.17 \pm 13.20 \mu \mathrm{g}\right.$. $\mathrm{L}^{-1}$ vs. $\left.20.67 \pm 12.35 \mu \mathrm{g} . \mathrm{L}^{-1}\right)$. VC\% values above 35 were also observed for total nitrogen (47.25 in the dry season; 35.82 in the rainy season) and for total phosphorus (51.17 in the rainy season) (Table 3).

When the data were analyzed with the $t$ test, the rainy and the dry season differed significantly $(p<0.05)$ with regard to seven chemical and physical variables, but not total phosphorus, total nitrogen or salinity. This last variable was considered constant throughout the two seasons. Some of variables displayed no significant temporal variation at specific sampling locations (e.g. temperature, $\mathrm{pH}$ and dissolved oxygen at LIMN2, conductivity at
$300 \mathrm{C}$, and $\mathrm{pH}$ at $180 \mathrm{C}$ and LIMN1), but seasonal differences in chlorophyll $a$ were significant at all four locations (Table 4).

Locations 180C, 300C and LIMN1 differed significantly with regard to temperature (Table 4). Moreover, the average temperature and $\mathrm{VC} \%$ were higher in the rainy season $\left(28.63^{\circ} \mathrm{C}\right.$ and 1.07$)$ than in the dry season $\left(28.15^{\circ} \mathrm{C}\right.$ and 0.77$)$ (Table 3$)$. In addition, surface water temperatures rose in the rainy season, increasing the difference between surface and bottom temperatures (Figure 4).

According to information published by COGERH (a public water resource management agency), the Sítios Novos reservoir ranged between mesotrophic and hypereutrophic in the period 2008-2013 (COGERH, 2013). When the data collected for the present study were used to calculate the TSI according to CETESB (2009) (a government environmental sanitation agency) guidelines the Sítios Novos reservoir was found to be supereutrophic in the rainy season and supereutrophic to hypereutrophic in the dry season. Trophic state was based on average phosphorus and chlorophyll $a$ levels in the rainy season (TSI=66.19) and in the dry season (TSI=67.87).
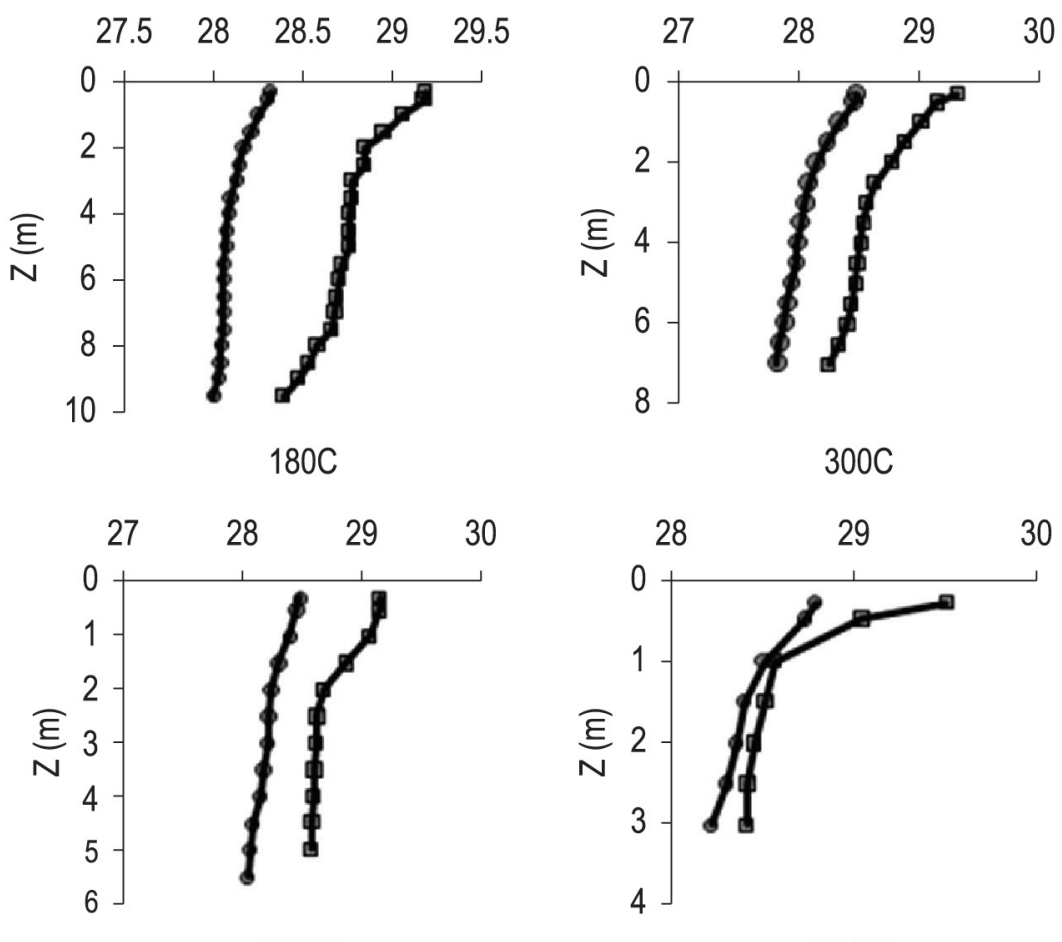

LIMN1

LIMN2

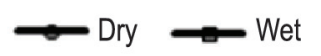

Figure 4. Temperatures $\left({ }^{\circ} \mathrm{C}\right)$ in the water column at four sampling locations (180C, 300C, LIMN1 and LIMN2) in the Sítios Novos reservoir (Ceará, Brazil), comparing the rainy season to the dry season in the period 2010-2011. 
The volume development index (VDI>2) calculated for the Sítios Novos reservoir indicates a concave basin, while the shoreline development index $(3<\mathrm{SDI}<5)$ reveals an irregular shoreline. The relative depth was small $(\mathrm{Zr}=0.25 \%)$. The bathymetric readings suggest the lake bed at $180 \mathrm{C}$, $300 \mathrm{C}$ and LIMN1 is morphometrically similar, as opposed to LIMN2 (Figure 5). Regardless of sampling location, the winds blew constantly from the northeast or the southeast at an average speed of $10.38 \pm 8.93 \mathrm{~m} . \mathrm{s}^{-1}$ and $16.37 \pm 13.74 \mathrm{~m} . \mathrm{s}^{-1}$, respectively, with the lowest speeds in the rainy season.

\section{Discussion}

The physical and chemical variables evaluated at different locations and seasons in the Sítios Novos reservoir suggest a profile of limnological variability not directly related to intensive aquaculture. The absence of large differences between the four sampling locations may be explained by the semiarid climate influence, the eutrophic state of the ecosystem, the shallow depth of the reservoir, and the circulation in the water column. This variability is likely related to morphometric differences between the sampling locations and is expressed mostly in turbidity and chlorophyll $a$ levels. In contrast, seasonal variations were pronounced, mostly due to the effect of increased rainfalls on physical and chemical stability.

In this study, physical and chemical variability in the Sítios Novos reservoir was characterized by more variation between seasons (dry and rainy) than between sampling locations. The meteorological

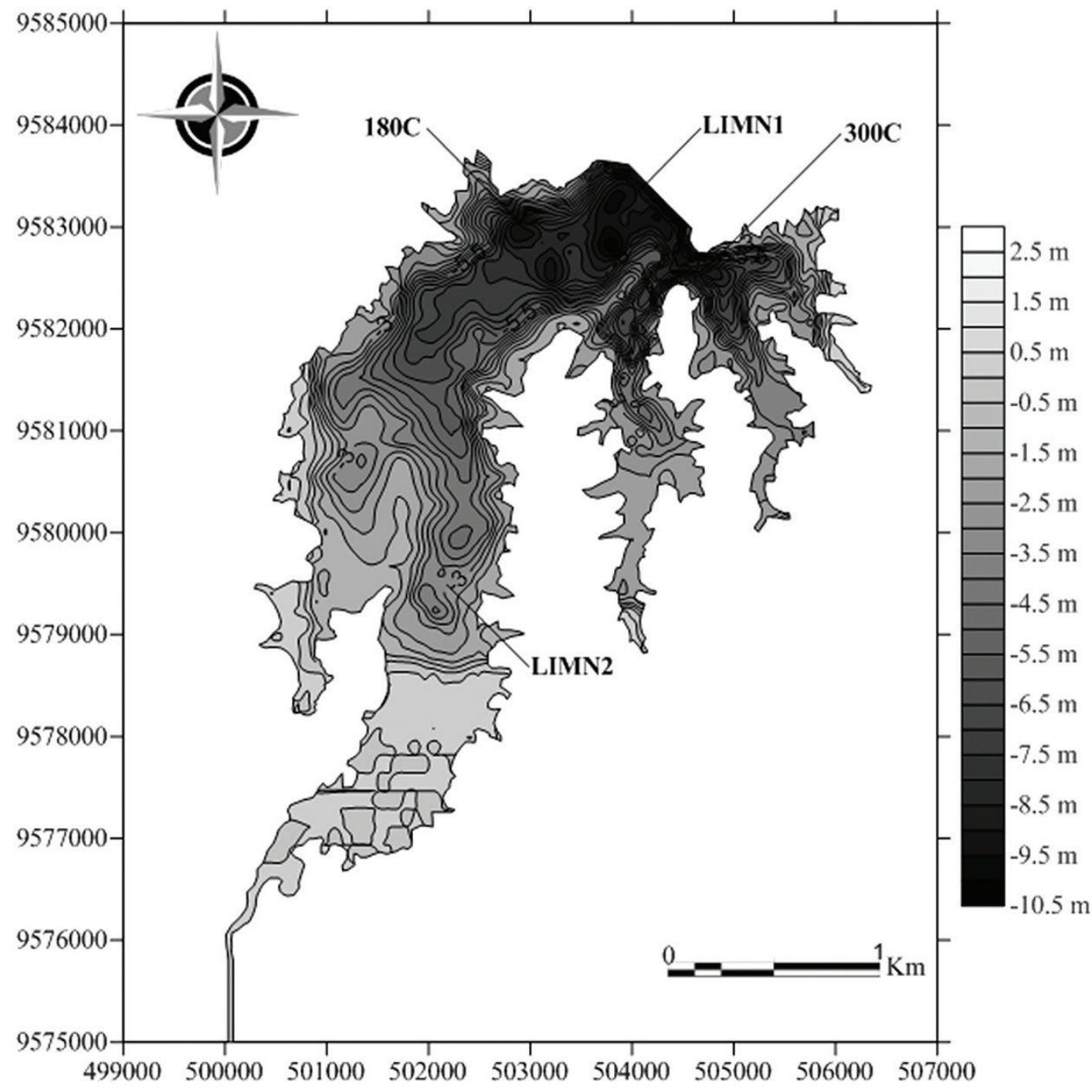

Figure 5. Bathymetry of the Sítios Novos reservoir (Ceará, Brazil) in gray scale. The $0 \mathrm{~m}$ depth corresponds to the $40.17 \mathrm{~m}$ quota based in datum WGS84 (Golden Software, 2013). 
profile was one of scarce rain and constant winds. Morphometrically, the reservoir is concave and shallow, with an irregular shoreline. Finally, the calculated trophic status index shows the reservoir to be supereutrophic in the rainy season and supereutrophic to hypereutrophic in the dry season.

These characteristics are typical of reservoirs in semiarid Northeastern Brazil (Freire et al., 2009; Barbosa et al., 2012). Due to ample circulation throughout the day, the water column in such ecosystems may be considered polymictic (Esteves and Furtado, 2011). In fact, the strong constant winds blowing over the Sítios Novos reservoir, primarily from the southeast, cause the water in the column to blend, especially in view of the small relative depth of the reservoir $(0.25 \%)$ (Aldama et al., 2013). In addition, the concave shape of the reservoir favors water circulation (Fantin-Cruz et al., 2008). La Mer and Healy (1965) attributed a movement of $1 / 30$ to a surface monolayer subject to winds at $0.85 \mathrm{~m} . \mathrm{s}^{-1}$; thus, on the windward side, wind speeds 23.5 times greater than this can cause considerable renovation.

The smallest total depths were registered at LIMN2. The high turbidity and chlorophyll $a$ values at this location may be explained by the resuspension of sediments due to the effect of the wind (Talling, 2001). In addition to the small depth, large amounts of sediments are deposited at LIMN2 by the São Gonçalo river, especially in the rainy season. As observed by Freire et al. (2009) for the Pacajus reservoir (Ceará, Brazil), ecotones between lotic and lentic environments tend to display high levels of turbidity (Wetzel, 1992) and chlorophyll a. The limnological conditions at LIMN2 are also affected by the presence of Copernicia prunifera ("carnaubeiras") which thrive in nutrient-rich alluvial deposits (Balslev et al., 2011).

The morphometry and the accumulation of sediments and nutrients were positively associated with greater physical and chemical variability at LIMN2. Variability was significantly smaller between the other sampling locations (180C, 300C and LIMN1) due to similarities in bathymetry and morphometry, as suggested by the bathymetric isolines of the reservoir. Despite the importance of bathymetry to physical and chemical variability, bathymetrically similar locations with and without intensive aquaculture facilities differed significantly with regard to $\mathrm{pH}$ values.

The $\mathrm{pH}$ variability is important in aquatic ecosystems: small changes represent substantial variations in environmental $\mathrm{H}^{+}$ion concentrations.
The increased $\mathrm{pH}$ values observed at $180 \mathrm{C}, 300 \mathrm{C}$ and LIMN1 may be related to the nearby fish farming facilities (Starling et al., 2002). However, a different experimental study design would be required to evaluate the specific association between changes in $\mathrm{pH}$ values and intensive aquaculture in a reservoir like Sítios Novos, characterized by small relative depth, irregular margins, multiple localized sources of pollution, a eutrophic status between supereutrophic and hypereutrophic, sturdy winds and blending of the water in the column.

Seasonal factors such as rainfall (concentrated in the months of February, March and April) produced greater physical and chemical changes in the Sítios Novos reservoir than did the proximity to fish farming facilities and differences in bathymetry and morphology. Aquatic ecosystems in semiarid Northeastern Brazil tend to suffer dramatic physical and chemical changes during the rainy season (Freire et al., 2009; Molisani et al., 2010) and the Sítios Novos reservoir is no exception. At this time of the year, the management and water quality monitoring of reservoirs with large storage capacity should be given special attention.

Rain and wind play a crucial role in the warming dynamics of tropical lakes as observed by water temperature dynamic in water column of the Sítios Novos reservoir. This variable varied significantly between the dry season and the rainy season, except at LIMN2, possibly due to the smaller depth. The southeastern wind was less intense in the rainy season $\left(6.17 \pm 3.07 \mathrm{~m} . \mathrm{s}^{-1}\right)$ than in the dry season $\left(26.57 \pm 12.40 \mathrm{~m} \cdot \mathrm{s}^{-1}\right)$, leading to a temperature increase in the water column, especially near the surface, and increased variability at deeper locations (Lewis JR, 1982). In shallower locations such as LIMN2, a greater surface/volume ratio potentially leads to higher evaporation rates and higher and more stable temperatures in the surface layer (Sherwood and $\mathrm{Fu}, 2014$ ).

Not only do phosphorus and nitrogen concentrations increase as a result of rainfalls, but the irregular shoreline of the Sítios Novos reservoir (Ds=4.76) favor the input of sediments and nutrients, especially in the rainy season. The total phosphorus concentrations (TP) observed at all sampling locations and in both seasons are typical of hypereutrophic environments ( $\left.\mathrm{TP} \geq 100 \mu \mathrm{g} \cdot \mathrm{L}^{-1}\right)$, as defined by the CETESB (2009), by the Organization for Economic Cooperation and Development (OECD, 1982) and by Wetzel (2001). The STI values calculated from the data collected for this study highlight the importance of high chlorophyll 
a levels in the dry season to the determination of a reservoir's trophic status. These changes in chlorophyll $a$ levels explain the reclassification of the Sítios Novos reservoir from supereutrophic in the rainy season to hypereutrophic in the dry season.

The observed increase in total phosphorus concentrations the Sítios Novos reservoir during the rainy season was due to the input of sediments and nutrients from the reservoir margins and from the São Gonçalo river (Moss et al., 2011; Withers et al., 2009); in other words, seasonal changes in phosphorus and chlorophyll $a$ levels were not directly correlated. According to Molisani et al. (2010), the absence of a correlation between phosphorus and chlorophyll a suggests the former is not a limiting factor to the growth of phytoplankton in Castanhão, a large reservoir in semiarid Northeastern Brazil. The finding of decreased levels of chlorophyll $a$ in the Sítios Novos reservoir during the rainy season suggests a similar scenario. In this case, the limiting factor may be nitrogen, considering the presence of $\mathrm{N}_{2}$-fixing cyanobacteria, a common finding in eutrophic aquatic ecosystems (Conley et al., 2009).

On the other hand, in this study variations in average chlorophyll $a$ levels between sampling locations and seasons were positively correlated with variations in turbidity (Pearson, $\mathrm{r}=0.59 ; p<0.01$ ), as reported for other reservoirs in the semiarid Northeast and Southeast of Brazil (Câmara et al., 2009; Crossetti et al., 2008). Changes in the concentration of chlorophyll $a$ may be associated not only with total nitrogen levels, but also with water circulation (Crossetti et al., 2008), light intensity (Tundisi and Matsumura-Tundisi, 2008) and the presence of omnivorous and planktivorous fishes (Mazumder et al., 1990; Lazzaro et al., 2003), among other factors.

Salinity and conductivity did not vary between seasons or sampling locations. The physical and chemical parameters which did vary between sampling locations were possibly related to differences in soil morphology (not evaluated in this study) and trophic status, matching the findings of other studies on reservoirs in semiarid regions (Lucca et al., 2008; Câmara et al., 2009).

In conclusion, Sítios Novos is a shallow reservoir with little vertical and horizontal variability of the physical and chemical parameters of the water column. Differences were greater between seasons (dry vs. rainy) than between sampling locations. This may be explained by the seasonality of rainfalls, circulation in the water column and a range of morphometric aspects, including maximum depth, relative depth and volume and shoreline development. In the rainy season, physical and chemical variability was greater, especially at deeper locations, and total phosphorus and total nitrogen levels were higher. During most of the year, variations in turbidity, oxygen demand, dissolved oxygen and chlorophyll $a$ levels were substantial at all sampling locations in the Sítios Novos reservoir, but especially so in the lotic-lentic ecotone near the debouch of the river due to the greater input and accumulation of nutrients and sediments, even when compared to locations impacted by intensive fish farming.

\section{Acknowledgments}

The authors would like to thank the Companhia de Gestão de Recursos Hídricos (COGERH), specially Francimeyre Avelino, Edmundo Rodrigues and Deilton Holanda for logistic support, to staff of Aquatic Ecology Laboratory (Laboratório de Ecologia Aquática/UFC), to Paulo César Colonna Rosman for support with SisBaHia ${ }^{\circledR}$ and to project PPP/FUNCAP (Fundação Cearense de Apoio ao Desenvolvimento Científico e Tecnológico) (GPF 2153/85) for equipment and supplies.

\section{References}

ALDAMA, GR., PONCE PALAFOX, JT., CRUZ, LFG., HERNÁNDEZ, DO., DÍAZ, JA. and ARREDONDO-FIGUEROA, JL. 2013. Morphometric characteristics of tropical shallow reservoir used for aquaculture and agriculture in the mexican plateau. Revista Bio Ciencias, vol. 2, no. 2, p. 83-88.

ANSAH, YB., FRIMPONG, EA. and AMISAH, S. 2012. Biological assessment of aquaculture effects on effluent-receiving streams in ghana using structural and functional composition of fish and macroinvertebrate assemblages. Environmental Management, vol. 50, no. 1, p. 166-180. PMid:22555961. http://dx.doi. org/10.1007/s00267-012-9858-x

American Public Health Association - APHA. 2005. Standard methods for the examination of water and wastewater. 21th ed. Washington.

Asociación para la promoción de la geomática libre y el desarrollo de gvSIG - Asociación gvSIG. 2014. Free gvSIG for Windows. Version 1.11.0 final.

BARBOSA, JEL., MEDEIROS, ESF., BRASIL, J., CORDEIRO, RSC., CRISPIM, MCB. and SILVA, GHG. 2012. Aquatic systems in semi-arid Brazil: limnology and management. Acta Limnologica Brasiliensia, vol. 40, no. 1, p. 103-118.

BALSLEV, H., KAHN, F., MILLAN, B., SVENNING, JC., KRISTIANSEN, T., BORCHSENIUS, F., 
PEDERSEN, D. and EISERHARDT, WL. 2011. Species diversity an growth forms in tropic american palm communities. The Botanical Review, vol. 77, no. 4, p. 381-425. http://dx.doi.org/10.1007/ s12229-011-9084-x

BORGES, PAF., TRAIN, S., DIAS, JD. and BONECKER, CC. 2010. Effects of fish farming on plankton structure in a Brazilian tropical reservoir. Hydrobiologia, vol. 649, no. 1, p. 279-291. http:// dx.doi.org/10.1007/s10750-010-0271-2

CÂMARA, FRA., LIMA, AKA., ROCHA, O. and CHELLAPPA, NT. 2009. The role of nutrient dynamics on the phytoplankton biomass (chlorophyll-a) of a reservoir-channel continuum in a semi-arid tropical region. Acta Limnologica Brasiliensia, vol. 21, no. 4, p. 431-439.

CARLSON, RE. 1977. A trophic state index for lakes. Lymnology an Oceanography, vol. 22, no. 2, p. 361369.

CARPENTER, SR., CHISHOLM, SW., KREBS, CJ., SCHINDLER, DW. and WRIGHT, RF. 1995. Ecosystem experiments. Science, vol. 269, no. 5222, p. 324-327. PMid:17841247. http://dx.doi. org/10.1126/science.269.5222.324

CARPENTER, SR., BROCK, WA., COLE, JJ., KITCHELL, JF. and PACE, ML. 2008. Leading indicators of trophic cascades. Ecology Letters, vol. 11, no. 2, p. 128-138. PMid:18021242

Companhia Ambiental do Estado do Sáo Paulo - CETESB. 2009. Relatório de qualidade das águas superficiais no Estado de São Paulo. São Paulo. Available from: <http://www.cetesb.sp.gov.br/ tecnologia-ambiental/laboratorios/61-publicacoese-relatorios---relatorios-de-qualidade>. Access in: 20 feb. 2014.

Companhia de Gestáo dos Recursos Hídricos - COGERH. 2008. Inventário ambiental do açude sitios novos: relatório de fatores condicionantes da qualidade das águas. São Paulo. Available from: <http://www.hidro.ce.gov.br/arquivos/invetarios/>. Access in: 6 feb. 2014.

Companhia de Gestáo dos Recursos Hídricos - COGERH. 2013. Portal hidrológico do Ceará. Ceará. Available from: <http://www.hidro. ce.gov.br/reservatorios/qualidade/eutrofizacao $>$. Access in: 6 feb. 2014.

CONLEY, DJ., PAERL, HW., HOWARTH, RW., BOESCH, DF., SEITZINGER, SP., HAVENS, KE., LANCELOT, C. and LIKENS, GE. 2009. Controlling eutrophication: nitrogen and phosphorus. Science, vol. 323, no. 5917, p. 1014-1015. PMid:19229022. http://dx.doi.org/10.1126/science.1167755

COZE, AS. and NAVA, AF. 2009. Review of environmental impact assessment and monitoring of aquaculture in Latin America. In Food and Agriculture Organization of the United Nations - FAO. Environmental impact assessment and monitoring of aquaculture. Rome. p. 395-454. FAO Fisheries and Aquaculture Technical Paper 527.

CROsseTTI, LO., BICUDO, DC., BICUDO, CEM. and BINI, LM. 2008. Phytoplankton biodiversity changes in a shallow tropical reservoir during the hypertrophication process. Brazilian Journal of Biology, vol. 68, no. 4, p. 1061-1067. PMid:19197476. http://dx.doi.org/10.1590/S151969842008000500013

DIAS, JD., SIMÓES, NR. and BONECKER, CC. 2012a. Net cages in fish farming: a scientometric analysis. Acta Limnologica Brasiliensia, vol. 24, no. 1, p. 12-17. http://dx.doi.org/10.1590/S2179975X2012005000022

DIAS, JD., SIMÓES, NR. and BONECKER, CC. 2012b. Zooplankton community resilience and aquatic environmental stability on aquaculture practices: a study using net cages. Brazilian Journal of Biology, vol. 72, no. 1, p. 1-11. PMid:22437379

ESTEVES, FA. and FURTADO, ALS. 2011. Oxigênio dissolvido. In ESTEVES, FA., org. Fundamentos de limnologia. 3th ed. Rio de Janeiro: Interciência. 826 p.

FANTIN-CRUZ, I., LOVERDE-OLIVEIRA, S. and GIRARD, P. 2008. Caracterização morfométrica e suas implicaçóes na limnologia de lagoas do Pantanal Norte. Acta Scientiarum. Biological Sciences, vol. 30, no. 2, p. 133-140.

FREIRE, RHF., CALIJURI, MC. and SANTANELLA, ST. 2009. Longitudinal patterns and variations in water quality in a reservoir in the semiarid region of NE Brazil: responses to hydrological and climatic changes. Acta Limnologica Brasiliensia, vol. 21, no. 2, p. 251-262.

Fundação COPPETEC. 2013. SisBaHia 9: Sistema Base de Hidrodinâmica Ambiental. Version 9.2. Rio de Janeiro: UFRJ.

Fundação Cearense de Meteorologia e Recursos Hídricos - FUNCEME. 2011a. Mapeamento dos espelhos d'água do Brasil. Ceará. Available from: <http://www.funceme.br/dmdocuments/espelhos_ dagua.pdf $>$. Access in: 5 oct. 2011

Fundação Cearense de Meteorologia e Recursos Hídricos - FUNCEME. 2011b. Portal hidrológico do Ceará. Ceará. Available from: <http://www.hidro. ce.gov.br/reservatorios/chuva/boletim-mensal>. Access in: 5 oct. 2011.

Golden Software. 2013. GraphPad PRISM 5 for Windows. Version 5.01. Golden.

LA MER, VK. and HEALY, TW. 1965. Evaporation of water: its retardation by monolayers. Science, vol. 148 , no. 3666, p. 36-42.

LAZZARO, X., BOUVY, M., RIBEIRO FILHO, RA., OLIVIERA, VS., SALES, LT. and VASCONCELOS, ARM. 2003. Do fish regulate phytoplankton in shallow eutrophic Northeast Brazilian reservoirs? 
Freshwater Biology, vol. 48, no. 4, p. 649-668. http:// dx.doi.org/10.1046/j.1365-2427.2003.01037.x

LEWIS JR., WM. 1982. Temperature, heat, and mixing in Lake Valencia, Venezuela. Limnology and Oceanography, vol. 28, no. 2, p. 273-286.

LINDIM, C., PINHO, JL. and VIEIRA, JMP. 2011. Analysis of spatial and temporal patterns in a large reservoir using water quality and hydrodynamic modeling. Ecological Modelling, vol. 222, no. 14, p. 2485-2494. http://dx.doi.org/10.1016/j. ecolmodel.2010.07.019

LUCCA, JV., ALBUQUERQUE, ALS. and ROCHA, O. 2008. Spatial heterogeneity and temporal changes of abiotic factors, in Lake Caçó, Maranhão State, Brazil. Acta Limnologica Brasiliensia, vol. 20, no. 2, p. 89-97.

MAZUMDER, A., TAYLOR, WD., MCQUEEN, DJ. and LEAN, DRS. 1990. Effects of fish and plankton on lake temperature and mixing depth. Science, vol. 247 , no. 4940 , p. 312-315. PMid:17735850. http://dx.doi.org/10.1126/science.247.4940.312

MEDEIROS, PH., GÜNTNER, A., FRANCKE, T., MAMEDE, GL. and ARAÚJO, J. 2010. Modelling spatio-temporal patterns of sediment yield and connectivity in a semi-arid catchment with the WASA-SED model. Hydrological Sciences Journal, vol. 55, no. 4, p. 636-648. http://dx.doi. org/10.1080/02626661003780409

MOLISANI, MM., MOREIRA, MOP., MONTE, TM., BARROSO, HS., HIJO, CAG., VASCONCELLOS, GH. and BECKER, H. 2010. Trophic state, phytoplankton assemblages and limnological diagnosis of the Castanhão Reservoir, CE, Brazil. Acta Limnologica Brasiliensia, vol. 22, no. 1, p. 1-12. http://dx.doi.org/10.4322/actalb.02201001

MOSS, B., HAVENS, K., KOSTEN, S., LACEROT, G., LIU, Z., MEERHOFF, M., BATTARBEE, RW., MEESTER, LD., JEPPESEN, E., MAZZEO, N., PAER, H. and SCHEFFER, M. 2011. Allied attack: climate change and eutrophication. Inland Waters, vol. 1, p. 101-105. http://dx.doi.org/10.5268/IW1.2.359

NAYLOR, RL., GOLDBURG, RJ., PRIMAVERA, JH., KAUTSKY, N., BEVERIDGE, MCM., CLAY, J., FOLKE, C., LUBCHENCOI, J., MOONEY, H. and TROELL, M. 2000. Effect of aquaculture on world fish supplies. Nature, vol. 405, no. 6790, p. 1017-1024. PMid:10890435. http://dx.doi. org/10.1038/35016500

NOVAES, RLM. and FELIX, S. 2013. Save Caatinga from drought disaster. Nature, vol. 498, no. 7453, p. 170. http://dx.doi.org/10.1038/498170a

Organization for Economic Cooperation and Development - OECD. 1982. Eutrophication of water: monitoring, assessment and control. Paris. 154 p.
PEEL, MC., FINLAYSON, BL. and MCMAHON, TA. 2007. Updated world map of the Köppen-Geiger climate classification. Hydrology and Earth System Sciences Discussion, vol. 4, p. 439-473. http://dx.doi. org/10.5194/hessd-4-439-2007

R Development Core Team. 2013. R: a language and environment for statistical computing. Vienna: R Foundation for Statistical Computing. Available from: <http://www.rproject.org/>.

REBOUÇAS, AC., BRAGA, B. and TUNDISI, JG. 2006. Águas doces no Brasil: capital ecológico, uso e conservação. 3th ed. São Paulo: Escrituras. 720 p.

SHERWOOD, S. and FU, Q. 2014. A drier future? Science, vol. 343, no. 6172, p. 737-739. PMid:24531959. http://dx.doi.org/10.1126/science. 1247620

STARLING, F., LAZZARO, X., CAVALCANTI, C. and MOREIRA, R. 2002. Contribution of omnivorous tilapia to eutrophication of a shallow tropical reservoir: evidence from a fish kill. Freshwater Biology, vol. 47, no. 12, p. 2443-2452. http://dx.doi. org/10.1046/j.1365-2427.2002.01013.x

TALLING, JF. 2001. Environmental controls on the functioning of shallow tropical lakes. Hydrobiologia, vol. 458 , no. $1-3$, p. $1-8$.

TUNDISI, JG. and MATSUMURA-TUNDISI, T. 2008. Limnologia. São Paulo: Oficina de Textos. 632 p.

TUNDISI, JG. 2008. Recursos hídricos no futuro: problemas e soluçóes. Estudos Avançados, vol. 22, no. 63, p. 7-16. http://dx.doi.org/10.1590/S010340142008000200002

WANG, G., XIE, J., YIN, G., YU, D., YU, E. and WANG, H. 2010. Influences of aquiculture on ecological environment. International Journal of Biology, vol. 2, no. 2, p. 158-164.

WELCH, BL. 1951. On the comparison of several mean values: an alternative approach. Biometrica, vol. 38, no. 3-4, p. 330-336. http://dx.doi.org/10.1093/ biomet/38.3-4.330

WETZEL, RG. 1992. Gradient-dominated ecosystems: sources and regulatory functions of dissolved organic matter in freshwater ecosystems. Hydrobiologia, vol. 229, no. 1, p. 181-198. http://dx.doi. org/10.1007/BF00007000

WETZEL, RG. 2001. Limnology. 3th ed. Philadelphia: W.B. Saunders. 743 p.

WITHERS, PJA., HARTIKAINEN, H., BARBERIS, E., FLYNN, NJ. and WARREN, GP. 2009. The effect of soil phosphorus on particulate phosphorus in land runoff. European Journal of Soil Science, vol. 60, no. 6, p. 994-1004. http://dx.doi.org/10.1111/j.13652389.2009.01161.x

ZAR, JH. 2010. Biostatistical analysis. 5th ed. New Jersey: Prentice Hall. 978 p. 